\title{
CORRELATION OF METABOLIC PROFILE AND BONE MINERAL DENSITY IN TREATMENT - NAIVE FEMALES WITH SUBCLINICAL THYROID DYSFUNCTION - A PILOT STUDY
}

\section{KORELACIJA METABOLIČKOG PROFILA I KOŠTANE GUSTINE KOD NETRETIRANIH ISPITANICA OBOLELIH OD SUPKLINIČKIH TIREOIDNIH DISFUNKCIJA - PILOT STUDIJA}

Marija Popin-Tarić', Zoran Gluvić', Vladimir Samardžić', Anita Vasić-Vlaisavljević', Jelena Tica Jevtić', Anastasija Panić2, Emina Sudar Milovanović2, Ratko Tomašević', Esma R. Isenović2 ${ }^{2,4}$

\section{Summary}

Introduction. It is well-known that overt thyroid dysfunctions have an influence on bone mineral density (BMD). It is noticed as a change in bone turnover and BMD, with subsequent increased risk of fall - induced fractures. Additionally, promoting the lipid profile derangement, subclinical thyroid dysfunction seems to be an important factor of atherosclerosis acceleration and the risk of cerebrovascular and cardiovascular incidents.

In this study we examined the relationship between some of osteoporosis risk factors, metabolic parameters and BMD, in subclinical thyroidopathies.

Material and Methods. Pilot cross - sectional study involved 45 females selected on fulfilled inclusion criteria. Three groups of 15 examinees were formed, based on TSH and fT4 serum levels (SHypo, SHyper, and euthyroid - control). As for risk factors, age, records on menopause and history of past fractures as well as metabolic parameters Body Mass Index (BMI), waist and hip circumference, cholesterol and triglyceride levels were observed. The entire study population was referred to DEXA (Dual Energy X Ray Absorptiometry) scan for BMD measurement on lumbar spine (LS) and left hip (LH), expressed through $\mathrm{T}$ scores. The obtained data were analyzed by SPSS for Windows 18.0 statistical package. The level of statistical significance was 0.05 .

Results. The groups of patients differed on cholesterol levels and LS/LH T scores. Decreased BMD was detected in 35 (77.4\%) patients. Intergroup correlations of LS/LH T scores were registered. A history of past fractures and records on menopause significantly influenced LS/LH T scores, which was not the case with metabolic parameters. Both the lowest $T$ scores and clinically important dyslipidemia were presented in SHypo group.

Discussion. The pilot study pointed out a decrease in BMD (mostly on osteopenia level) in subclinical, presumably hypothyroid disorder. The presence of hypercholesterolemia was detected in the same group. Metabolic parameters and thyroid hormones (TSH and fT4) did not have an effect on BMD.

Conclusion. Subclinical thyroid dysfunctions are associated with a decrease in BMD, mostly presented as osteopenia, with a higher degree of severity in SHypo group. There is no registered influence of metabolic parameters on LS/LH T scores.

It can be possible to slow down progression of decrease in BMD and subsequent fracture risk, with proper diagnostics and management of subclinical thyroid dysfunctions. Additionally, with correction of lipid disorders, cardiovascular and cerebrovascular risk could be minimized.

Key words: subclinical hypothyroidism, subclinical hyperthyroidism, Bone Mineral Density, osteopenia

\section{Sažetak}

Uvod: Poznat je uticaj manifestnih tireoidnih disfunkcija na promene u koštanoj masi koji se ispoljava kroz izmene u koštanom prometu, koje dovode do promena koštane gustine i mogućeg povećanog rizika od pada i preloma. Takođe, uticajem na metaboličke parametre, prevashodno na lipide, tireoidne disfunkcije predstavljaju važan uzrok akceleracije ateroskleroze i povećanja cerebrovaskularnog i kardiovaskularnog rizika.

Ovom studijom je ispitivan metabolički profil i koštana gustina kod pacijenata sa dijagnostikovanom supkliničkom tireoidnom disfunkcijom.

Materijal i metode: Pilot studija preseka obuhvatila je 45 selektovanih ispitanica, koje su ispunile inkluzione kriterijume. Na osnovu nivoa tireostimulišućeg hormona (TSH) i slobodnog tiroksina (fT4) ispitanice su svrstane u 3 grupe, po 15 ispitanica u svakoj grupi: - grupa: supklinička hipotireoza (SHipo), grupa: supklinička hipertireoza (SHiper), i grupa: eutireodna-tj. kontrolna grupa. Od faktora rizika, praćeni su godine života, podaci o menopauzi i prethodnim prelomima, a od metaboličkih parametara indeks telesne mase (engl. Body Mass Index, BMI), obim struka (OS), obim kuka (OK), nivo triglicerida i nivo ukupnog holesterola. Kod svih ispitanica je merena koštana gustina na lumbalnoj kičmi i levom kuku (LK) i izražena u T skorovima. Dobijeni podaci su analizirani koriščćenjem statističkog paketa SPSS za Windows. Statistički značajnom je smatrana verovatnoća manja od 0,05 ( $<<0,05)$. 
Rezultati: Grupe ispitanica su se značajno razlikovale po nivoima ukupnog holesterola, kao i T skorovima lumbalne kičme i LK. Smanjena koštana gustina je registrovana kod 35 (77,8\%) ispitanica. Vrednosti T skorova lumbalne kičme i LK su unutargrupno međusobno korelisali. Od faktora rizika, postojanje prethodnih preloma i menopauze, značajno utiču na T skorove, što nije slučaj ni sa jednim metaboličkim parametrom. Najniži T skorovi, kao i sa kliničkog aspekta najznačajnija dislipidemija, su registrovani u grupi SHipo.

Diskusija: U okviru ove pilot studije pokazano je smanjenje koštane gustine u populaciji ispitanica sa supkliničkim tireoidopatijama, najviše izražena u SHipo grupi. U istoj grupi je zabeležen i klinički najaterogeniji lipidni profil (hiperholesterolemija). Metabolički parametri kao i hormoni nisu uticali na T skorove lumbalne kičme i LK.

Zaključak: Supkliničke tireoidne disfunkcije su povezane sa smanjenjem koštane gustine, izražene kroz T skorove na lumbalnoj kičmi i LK, i na njih nisu uticali metabolički parametri. Pravovremenom dijagnostikom i lečenjem tireoidnih disfunkcija, moguće je usporiti gubitak koštane mase, smanjiti rizik kako od pada tako i od preloma, pri čemu korekcijom lipidnog disbalansa se može smanjiti potencijalni cerebrovaskularni i kardiovaskularni rizik.

Ključne reči: supklinička hipotireoza, supklinička hipertireoza, koštana gustina, osteopenija

\section{UvoD}

Osteoporoza (Op) je najčešća metabolička bolest u kojoj su procesi razgradnje intenzivniji od procesa stvaranja nove kosti (1). Osnovna karakteristika Op je narušena mikroarhitektura koštanog tkiva, što ima za posledicu povećanu fragilnost kostiju. Takve kosti se mogu prelomiti nakon padova sa visine koja odgovara visini osobe (engl. Standing height) ili niže, ali i nakon minimalnih trauma, koje u uslovima normalne koštane gustine ne bi dovele do mikro ili makrofraktura $(2,3)$.

Supkliničke tireoidne disfunkcije u osnovi predstavljaju laboratorijsku dijagnozu, bez ili sa minimalno ispoljenim simptomima i kliničkim znacima (4). Značaj ovih disfunkcija je u njihovoj mogućoj progresiji u klinički manifestne oblike bolesti, kao i u uticaju na različite organe i organske sisteme, pre svega na kardiovaskularni, centralni i periferni nervni sistem, uticaj na metabolički status i skeletni sistem, prevashodno kroz uticaj na gustinu koštane mase i rizik od preloma $(4,5)$.

Supklinička hipotireoza (SHipo) se definiše laboratorijskim nalazom povišenog nivoa tireostimulišućeg hormona (TSH) i normalnih nivoa perifernih tireoidnih hormona (6-8). Prevalenca SHipo u opštoj populaciji, prema različitim studijama, iznosi od 1 do $20 \%$ (9-11). Hronični autoimuni tireoiditis se navodi kao najčešći uzrok nastanka SHipo (60-80\%). Ostali uzroci perzistentnog SHipo su: nedovoljno supstituisan klinički hipotireoidizam, radioablativna terapija autoimune difuzne strume, suptotalna tireoidektomija u lečenju difuzne ili nodozne strume, prekomerno unošenje jodida, stanja nakon subakutnog, bezbolnog, postpartalnog tireoiditisa ili zračenja vrata, a znatno ređe nedostatak jodida, genetski poremećaji sinteze tireoidnih hormona, kao i infiltrativne bolesti štitaste žlezde $(10,12)$.

Supklinička hipertireoza (SHiper) se karakteriše sniženim nivoom TSH, uz normalne vrednosti perifernih tireoidnih hormona. Prevalenca u opštoj populaciji iznosi od $0,6 \%$ do $16 \%$, i zavisi od donje granice referentnog opsega za TSH. Ukoliko se za donju referentnu granicu uzme vrednost TSH od 0,4 mIU/L, prevalenca iznosi $3,2 \%$, dok u slučaju cut-off vrednosti TSH od $0,1 \mathrm{mIU}$ -
/L, ona iznosi $0,7 \%(10,13)$. SHiper može biti endogena (toksični adenom, polinodozna struma, Grejvs-Bazedovljeva bolest, tiroiditis) ili egzogena (primena supresivne terapije L-tiroksinom nakon totalne tiroidektomije zbog papilarnog/folikularnog karcinoma štitaste žlezde, u tretmanu difuzne i nodozne strume ili jatrogenozbog neželjene prekomerne supstitucije hipotireoze) (8, $14,15)$.

U regulaciji koštanog metabolizma učestvuju brojni hormoni, među kojima bitnu ulogu imaju i TSH i hormoni štitaste žlezde (tiroksin- T4 i trijodtironin- T3). Efekat TSH hormona se ostvaruje vezivanjem TSH za TSH receptore, koji su detektovani na prekursorima osteoblasta i osteoklasta (16). Pored toga, pokazano je i da periferni tireoidni hormoni mogu direktno uticati na kost, na taj način što utiču na sekreciju ili delovanje drugih hormona, koji ostvaruju svoj efekat i na metabolizam kosti. Hormon TSH , takođe utiče i na remodelovanje kosti na taj način što smanjuje osteoklastnu aktivnost, kao i njihovo preživljavanje, a u manjoj meri na taj način što inhibira diferencijaciju osteoblasta i stvaranje kolagena tipa $1(16,17)$. Periferni tireoidni hormoni deluju na povećanje koštanog prometa, koji vodi ka smanjenju koštane gustine $(17,18)$.

Iako se zna da klinički hipotireoidizam i hipertireoidizam utiču na smanjenje koštane gustine i tako povećavaju rizik od Op preloma (19-21), uticaj supkliničkih tireoidnih disfunkcija je manje ispitivan, i vrlo često sa divergentnim rezultatima. SHiper, prevashodno zbog povišenih vrednosti T3 i T4, dovodi do ubrzanog koštanog prometa i smanjenja mineralne gustine kosti, češće do nivoa osteopenije, sa posledičnim povećanjem rizika od preloma $(22,23)$. Nasuprot tome, SHipo usporavanjem remodelovanja kosti dovodi do povećanja koštane gustine, sa manje konzistentnim podacima u pogledu preloma (24-26).

Ciljevi ove pilot studije su bili da se: 1 . Prikažu faktori rizika za osteoporozu (godine života, pušenje, prethodni prelomi i menopauza), metabolički parametri (indeks telesne mase (BMI), obim struka (OS), obim kuka (OK), 
nivo triglicerida i holesterola) i gustina koštane mase (T skor lumbalne kičme i levog kuka (LK)) po grupama ispitanica (SHipo, SHiper i eutireoidna-kontrolna grupa), 2. da se ispita da li postoji razlika u gustini koštane mase među grupama ispitanica, 3. da se ispita da li postoji uticaj posmatranih faktora rizika za Op, metaboličkih paramatara i nivoa TSH i slobodnog tiroksina (fT4) na gustinu koštane mase u ispitivanoj populaciji.

\section{MATERIJAL I METODE}

Ova pilot studija preseka sprovedena je na Klinici za internu medicinu KBC Zemun- Službi za endokrinologiju i dijabetes i Službi za gerijatriju, tokom 2013-2014. godine. Kriterijumi za uključivanje ispitanika u studiju bili su postojanje vrednosti nivoa TSH i fT4 u krvi i izmerena koštana gustina DEXA (engl. Dual Energy $X$ Ray Absorpionmetry) metodom, sa definisanim T skorom lumbalne kičme i LK. Prvo su iz populacije od interesa isključeni ispitanici muškog pola, da bi se izbegao uticaj pola kao konfaunding varijable, a potom $i$ ispitanice sa kliničkim hipotireoidizmom (povišen TSH, nizak fT4), odnosno kliničkim hipertireoidizmom (nizak TSH i povišen fT4). Ostali ekskluzioni kriterijumi su bili: anamnestički podatak o Op u familiji, bolovanje od bolesti ili upotreba lekova koji poznato utiču na smanjenje koštane gustine, prisustvo sistolne i/ili dijastolne hipertenzije (sistolni pritisak $\leq 120 \mathrm{mmHg}$, a dijastolni pritisak $\leq 80 \mathrm{mmHg}$ ) i dijabetesa (anamnestički i merenjem jutarnje glikemije našte na samomeraču za merenje glikemije marke Accu Chek, Roche Diagnostics; studijske inkluzione vrednosti od 4,0 do $6,0 \mathrm{mmol} / \mathrm{L}$ ) i rane prirodne ili arteficijalne menopauze. Nakon toga su selektovane ispitanice, ukupno 45, klasifikovane u odgovarajuće jednake grupe po 15 ispitanica: grupa: SHipo $(\mathrm{TSH}=4-15 \mathrm{mIU} / \mathrm{ml}$, fT4=10-22 $\mathrm{pmol} / \mathrm{L})$, grupa: SHiper $(\mathrm{TSH}<0,4 \mathrm{mIU} / \mathrm{ml}, \mathrm{fT} 4=10-22 \mathrm{pmol} / \mathrm{L})$ i eutireoidnu, kontrolnu grupu (TSH=0,4-4,0 $\mathrm{mIU} / \mathrm{ml}$, fT4=10-22 pmol/L). Nivoi TSH i fT4 određivani su na automatskim analizatorima Immulite 2000. Referentan opseg za TSH je 0,4-4,0 mIU/ml, dok za fT4 iznosi 10 $22 \mathrm{pmol} / \mathrm{L}$.

Od faktora rizika za smanjenu koštanu gustinu, analizirani su postojanje menopauze, prethodnih preloma i navike pušenja.

Od metaboličkih parametara praćeni su BMI, OS, OK, kao i nivo ukupnog holesterola i triglicerida.

BMI predstavlja odnos telesne težine i kvadrata telesne visine, izražen u $\mathrm{kg} / \mathrm{m}^{2}$. OS i OK su mereni metrom, a izraženi u cm. OS >88 $\mathrm{cm}$ za žene, tj. odnos OS i OK (engl. waist/hip ratio) $>0,9$ za žene, su markeri centralne gojaznosti i insulinske rezistencije kao i povećanog kardiovaskularnog rizika.
Nivo holesterola i triglicerida određivan je aparatom Ilab $650 \mathrm{u}$ istoj laboratoriji. Referentne vrednosti za ukupni holesterol su 3,6-5,1 $\mathrm{mmol} / \mathrm{L}$, a za trigliceride $<1,7 \mathrm{mmol} / \mathrm{L}$.

Koštana gustina je merena uređajem Hologic Discovery QDR-C, koji radi po DEXA principu. Merenje absorpcije X zraka vršeno je nad lumbalnom kičmom i LK i izraženo T skorovima. Potom su ispitanice klasifikovane po grupama na osnovu lošijeg T skora: manje od $-2,5$ je osteoporoza, između -2,5 i -1,0 je osteopenija, dok je između $-1,0$ i $+1,0$ normalna koštana gustina. Osteopenija $i$ osteoporoza su definisane kao smanjena koštana gustina.

\section{STATISTIČKa ObRAdA REZULTATA}

U statističkoj obradi rezultata korišćene su metode deskriptivne i analitičke statistike. Od metoda deskriptivne statistike korišćeni su relativni brojevi, mere centralne tendencije i mere varijabiliteta. Od mera centralne tendencije korišćena je aritmetička sredina, a od mera varijabiliteta standardna devijacija, interval i koeficijent varijacije. Za testiranje normalne raspodele numeričkih obeležja posmatranja koršćen je Kolmogorov Smirnov test.

Od metoda analitičke statistike korišćeni su testovi za procenu značajnosti povezanosti i razlike. Od testova za procenu značajnosti povezanosti korišćen je Spearmanov test korelacije ranga, dok je za procenu značajnosti razlike korišćen $\chi^{2}$ test. $U$ slučajevima gde je ispitivana značajnost razlike među tri grupe ispitanica, korišćena je jednofaktorska parametarska analiza varijanse (ANOVA).

Nivo statističke značajnosti je bio 0,05 , a visoke statističke značajnosti 0,01 . U obradi podataka korišćen je statistički paket SPSS for Windows, verzija 18.0 (SPSS Inc., Chicago, IL, USA).

\section{Rezultati}

Pilot-studijom je obuhvaćeno 45 ispitanica, prosečne životne dobi 54 \pm 9 (32-72 godina) godina, koja se nije razlikovala među grupama ispitanica $(\mathrm{F}=1,511, \mathrm{df} 1=2$, $\mathrm{df} 2=42 ; \mathrm{p}>0,05)$. Od ukupnog broja, 18 (40\%) ispitanica su pušači, dok je primarna menopauza registrovana kod $37(82,2 \%)$ ispitanica. Prethodni prelomi su registrovani kod 4 (8,9\%) ispitanice. Tabelom br. 1 i Tabelom br. 2 su prikazani antropometrijski i metabolički parametri $\mathrm{u}$ ispitivanoj populaciji i po grupama ispitanica.

Posthok analizom statistički značajnih razlika u T skorovima na lumbalnoj kičmi (LS) i levom kuku (LK), najveći doprinos statističkoj značajnosti dala je razlika u T skorovima među grupama supkliničke hipotireoze i eutiroidne grupe (T skor LS kičma/LK SCHipo: kontrolna grupa, $\mathrm{p}<0,01$ ). 
Tabela 1. Deskriptivna statistika numeričkih parametara ispitivane populacije

\begin{tabular}{|c|c|c|c|}
\hline Varijabla & $\begin{array}{l}\text { Aritm. sredina } \pm \text { SD } \\
(\text { min-max) }\end{array}$ & $\begin{array}{l}\text { ANOVA } \\
{[F ; d f 1=2,} \\
\text { df } 2=42]\end{array}$ & p \\
\hline $\begin{array}{l}\text { BMI } \\
(\mathrm{kg} / \mathrm{m} 2)\end{array}$ & $\begin{array}{l}26,1 \pm 4,9 \\
(17,5-37,1)\end{array}$ & 1,052 & ns \\
\hline OS $(\mathrm{cm})$ & $\begin{array}{l}84 \pm 13 \\
(60-110)\end{array}$ & 0,927 & ns \\
\hline $\mathrm{OK}(\mathrm{cm})$ & $\begin{array}{l}104 \pm 10 \\
(88-135)\end{array}$ & 2,210 & ns \\
\hline $\begin{array}{l}\text { TSH } \\
(\mathrm{mIU} / \mathrm{ml})\end{array}$ & $\begin{array}{l}3,9 \pm 4,5 \\
(0,0-10,6)\end{array}$ & 35,266 & $\mathrm{p}<0,01$ \\
\hline $\begin{array}{l}\text { fT4 } \\
(\mathrm{pmol} / \mathrm{L})\end{array}$ & $\begin{array}{l}15,8 \pm 4,3 \\
(7,2-25,2)\end{array}$ & 10,464 & $\mathrm{p}<0,01$ \\
\hline $\begin{array}{l}\text { Trigliceridi } \\
(\mathrm{mmol} / \mathrm{L})\end{array}$ & $\begin{array}{l}1,64 \pm 0,64 \\
(0,6-4,2)\end{array}$ & 1,026 & ns \\
\hline $\begin{array}{l}\text { Holesterol } \\
(\mathrm{mmol} / \mathrm{L})\end{array}$ & $\begin{array}{l}5,2 \pm 1,2 \\
(3,3-8,0)\end{array}$ & 3,129 & $\mathrm{p}<0,05$ \\
\hline T skor, LS & $\begin{array}{l}-1,2 \pm 1,1 \\
(-3,6-0,8)\end{array}$ & 4,585 & $\mathrm{p}<0,05^{*}$ \\
\hline T skor, LK & $\begin{array}{l}-0,8 \pm 1,0 \\
(-4,4-0,8)\end{array}$ & 6,430 & $\mathrm{p}<0,01^{*}$ \\
\hline
\end{tabular}

BMI- indeks telesne mase; OS- obim struka; OK- obim kuka; TSH- tirostimulišući hormon; fT4-slobodni tiroksin, p-statistička značajnost
Klasifikovanjem T skorova po kategorijama, normalna koštana gustina, osteopenija i osteoporoza su registrovane kod 17 (37,8\%), 18 (40\%), odnosno kod $10(22,2 \%)$ ispitanica. Patološki nalaz osteopenije/osteoporoze po grupama ispitanica (SHipo kod 14, SHiper kod 9, Eutireoidna grupa kod 5 ispitanica) se statistički značajno razlikovao $\left(\chi^{2}=13,776, p<0,01\right)$.

Registrovana je statistički značajna korelacija između $\mathrm{T}$ skorova lumbalne kičme i LK $(r=0,616, p<0,01)$. Uticaj godina života i metaboličkih parametara na T skor lumbalne kičme i LK prikazan je na Tabeli br. 3. Od posma-

Tabela 3. Koeficijenti korelacije posmatranih metaboličkih parametara i T skorova lumbalne kičme (LS) i levog kuka (LK)

\begin{tabular}{|l|l|l|l|}
\hline Varijabla & $\mathbf{r}_{\text {T skor LS }}$ & $\mathbf{r}_{\text {T skor LK }}$ & $\mathbf{p}$ \\
\hline BMI (kg/m²) & 0,18 & 0,27 & $>0,05, \mathrm{~ns}$ \\
\hline OS $(\mathbf{c m})$ & 0,01 & 0,01 & $>0,05, \mathrm{~ns}$ \\
\hline OK $(\mathbf{c m})$ & 0,11 & 0,19 & $>0,05, \mathrm{~ns}$ \\
\hline Trigliceridi (mmol/L) & 0,01 & 0,20 & $>0,05, \mathrm{~ns}$ \\
\hline Holesterol (mmol/L) & $-0,04$ & $-0,07$ & $>0,05, \mathrm{~ns}$ \\
\hline
\end{tabular}

BMI- indeks telesne mase; OS - obim struka; OK- obim kuka; $r$-koeficijent korelacije; p-statistička značajnost

Tabela 2. Antropometrijski i metabolicki parametri po grupama ispitanica

\begin{tabular}{|c|c|c|c|}
\hline Varijabla & SHipo & SHiper & Eutireoidna \\
\hline $\begin{array}{l}\text { Godine života } \\
{[\mathrm{X} \pm \mathrm{SD} \text { (min-max)] }}\end{array}$ & $55 \pm 7(38-65)$ & $57 \pm 10(33-72)$ & $51 \pm 10(32-65)$ \\
\hline $\begin{array}{l}\text { BMI } \\
{[\mathrm{X} \pm \mathrm{SD}(\text { min-max })]}\end{array}$ & $\begin{array}{c}26,5 \pm 5,8 \\
(18,8-37,0)\end{array}$ & $\begin{array}{c}24,7 \pm 4,2 \\
(17,5-34,7)\end{array}$ & $\begin{array}{c}27,2 \pm 4,5 \\
(19,8-37,1)\end{array}$ \\
\hline Pušenje [da (\%)] & $5(33,3)$ & $7(46,7)$ & $6(40)$ \\
\hline $\begin{array}{l}\text { Prethodni prelomi } \\
\text { [da (\%)] }\end{array}$ & $3(20)$ & $1(6,7)$ & 0 \\
\hline Menopauza [da (\%)] & $14(93,3)$ & $14(93,3)$ & $9(60)$ \\
\hline $\begin{array}{l}\text { OS }(\mathrm{cm}) \\
{[\mathrm{X} \pm \mathrm{SD}(\min -\mathrm{max})]}\end{array}$ & $87,5 \pm 11,5(66-102)$ & $82 \pm 11(60-103)$ & $82 \pm 15(60-110)$ \\
\hline $\begin{array}{l}\mathrm{OK}(\mathrm{cm}) \\
{[\mathrm{X} \pm \mathrm{SD}(\min -\mathrm{max})]}\end{array}$ & $106 \pm 9(97-126)$ & $100 \pm 8(88-117)$ & $107 \pm 12(89-135)$ \\
\hline $\begin{array}{l}\text { TSH }(\mathrm{mIU} / \mathrm{ml}) \\
{[\mathrm{X} \pm \mathrm{SD}(\mathrm{min}-\mathrm{max})]}\end{array}$ & $8,6 \pm 4,8(5,1-20,6)$ & $0,1 \pm 0,1(0,0-0,39)$ & $3,0 \pm 0,7(1,9-4,0)$ \\
\hline $\begin{array}{l}\text { fT4 }(\mathrm{pmol} / \mathrm{L}) \\
{[\mathrm{X} \pm \mathrm{SD}(\min -\mathrm{max})]}\end{array}$ & $12,4 \pm 3,7(7,2-19,4)$ & $18,2 \pm 4,3(11-25,2)$ & $16,7 \pm 2,6(12,1-21,2)$ \\
\hline $\begin{array}{l}\text { Trigliceridi }(\mathrm{mmol} / \mathrm{L}) \\
{[\mathrm{X} \pm \mathrm{SD}(\min -\mathrm{max})]}\end{array}$ & $1,7 \pm 0,9(0,6-4,2)$ & $1,4 \pm 0,3(0,9-2,0)$ & $1,7 \pm, 5(0,9-2,8)$ \\
\hline $\begin{array}{l}\text { Holesterol }(\mathrm{mmol} / \mathrm{L}) \\
{[\mathrm{X} \pm \mathrm{SD}(\min -\mathrm{max})]}\end{array}$ & $5,7 \pm 1,5(3,4-8,0)$ & $4,7 \pm 0,8(3,3-6,7)$ & $5,2 \pm 0,9(3,4-7,2)$ \\
\hline $\begin{array}{l}\text { T skor LS } \\
{[\mathrm{X} \pm \mathrm{SD}(\min -\mathrm{max})]}\end{array}$ & $-1,7 \pm 0,8(-3,2-0,0)$ & $-1,4 \pm 1,2(-3,6-0,8)$ & $-0,6 \pm 0,9(-1,9-0,8)$ \\
\hline $\begin{array}{l}\text { T skor LK } \\
{[\mathrm{X} \pm \mathrm{SD}(\min -\max )]}\end{array}$ & $-1,3 \pm 0,7(-2,8-0,6)$ & $-0,9 \pm 1,3(-4,4-0,7)$ & $-0,1 \pm 0,5(-0,9-0,8)$ \\
\hline
\end{tabular}

BMI- indeks telesne mase; OS- obim struka; OK- obim kuka; TSH- tirostimulišući hormon; fT4- slobodni tiroksin; LS- lumbalna kičma, od eng. lumbal spine; LK- levi kuk; SHipo- grupa pacijenata sa subkliničkim hipotiroidizmom; SHiper-grupa pacijenata sa subkliničkim hipertiroidizmom; X-srednja vrednost; $S D$ - standardna devijacija 
A.

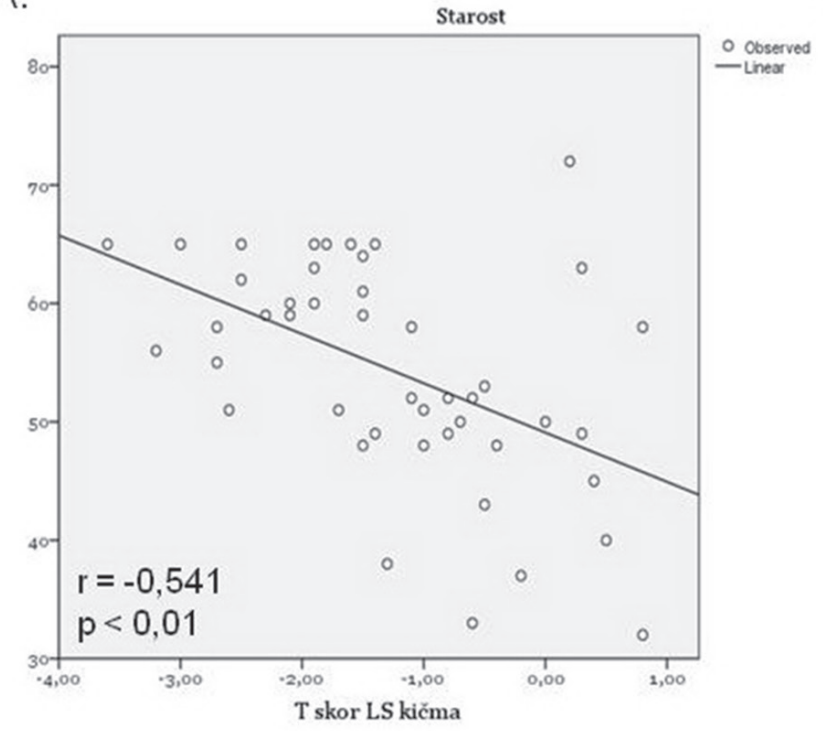

B.

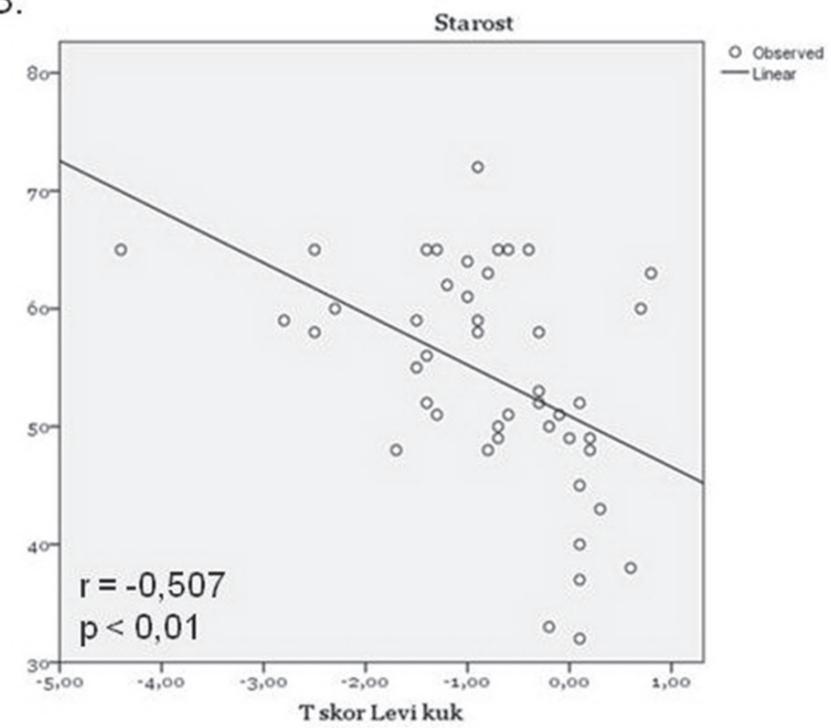

LS - lumbalna kičma; $r$ - koeficijent korelacije; $p$ - statistička značajnost

tranih faktora rizika za smanjenje koštane gustine u ovoj studiji, postojanje prethodnih preloma $\left(\rho_{\text {TskorLkiêma/prethodni- }}\right.$ prelom $\left.=0,29, \rho_{\text {TskorLK/prethodni prelom }}=0,33 ; \mathrm{p}<0,05\right)$ i menopauza $\left(\rho_{\text {TskorLkiěma/menopauza }}=0,53, \rho_{\text {TskorLK/menopauza }}=0,55 ; \mathrm{p}<0,01\right) \mathrm{su}$ uticali na T skorove lumbalne kičme i LK, dok u slučaju pušenja taj uticaj nije dostigao statističku značajnost $\left(\rho_{\text {TskorLkičma/pušenje }}=-0,068, \rho_{\text {TskorLK/pušenje }}=0,159 ; \mathrm{p}>0,05\right)$.

\section{Diskusija}

Pilot studija preseka, koja je obuhvatila 45 ispitanica podeljenih na osnovu nivoa TSH i fT4 na tri jednake grupe po 15 ispitanica (SHipo, SHiper, eutireoidna-kontrolna grupa), ukazala je na smanjenu koštanu gustinu na nivou osteopenije sto ukazuje da se koštana gustina značajno razlikovala među grupama ispitanica. Proaterogeni lipidni profil je prevashodno izražen u obolelih od SHipo. Prosečna koštana gustina, izražena kroz T skor na lumbalnoj kičmi i LK, je bila niža kod obolelih sa SHipo u odnosu na one sa SHiper i eutireoidne. Godine života ispitanica, prethodni prelomi i postojanje menopauze utiču na pomenute pokazatelje koštane gustine, dok taj uticaj nisu ostvarili navika pušenja, posmatrani metabolički parametri (BMI, OS, OK, nivo triglicerida i holesterola), kao i nivoi serumskog TSH i fT4. T skorovi lumbalne kičme i LK su međusobno pozitivno korelisali u ispitivanim grupama ispitanica.

Među poznatim faktorima rizika koji dovode do smanjenja koštane gustine, kako u našoj tako i studijama drugih autora, $(1,2,27,28)$, je ukazano na uticaj godina života, postojanja menopauze i podataka o prethodnim prelomima na vrednosti T skorova. Uporednom analizom sve tri grupe ispitanica u pogledu vrednosti T skorova, iako ta razlika nije dostigla statističku značajnost, oni su bili najniži u grupi ispitanica sa SHipo. Iako je broj ispitanica najvažnija limitacija naše studije, ovaj rezultat nije očekivan i razlikuje se od dosad objavljenih rezultata u literaturi $(1,2,27,28)$.

Studije na animalnim modelima su pokazale da izmenjeni nivoi TSH i perifernih tireoidnih hormona mogu nezavisno uticati na arhitekturu kosti uticajem na koštano remodelovanje $(16,18,29)$. Kod nokaut miševa za TSH receptor, pokazano je da je smanjen koštani promet rezultat povećanja resorpcije, koja nadilazi koštano formiranje (16). Takođe, primena TSH kod kastriranih ženki pacova dovela je do smanjenja koštanog gubitka sto je doprinelo poboljšanju mikroarhitekture kosti (30).

Dobro je dokumentovana povezanost kliničkih oblika disfunkcije štitaste žlezde sa poremećajima koštanog metabolizma $(4,5,13,21,31)$. Klinička hipertireoza udružena je sa povećanom koštanom resorpcijom, smanjenom gustinom koštane mase i povećanim rizikom od preloma (21,31), dok je klinička hipotireoza $(31,32)$ povezana sa sporijim koštanim prometom i povećanjem koštane gustine. Takođe su oscilacije izmerenih nivoa TSH u okviru referentnog opsega, udružene sa promenama u vrednostima koštane gustine. U studiji Morrisa i saradnika $(33,34)$ pokazano je da osobe, čiji je nivo TSH bliži donjim granicama referentnih vrednosti, imaju povećan rizik od osteopenije/ osteoporoze u odnosu na one čiji je nivo TSH bliži gornjim granicama referentnih vrednosti. Klinički hipertireoidizam je rizični faktor za prelome kostiju (21). Rizik od preloma kostiju je veći što je nivo TSH niži (35), a normalizuje se godinu dana nakon započinjanja tretmana tireostaticima (21). Iako je klinička hipertireoza značajan faktor rizika za Op i prelome $(21,36)$, rezultati studija koje su ispitivale uticaj SHiper na koštanu gustinu i rizik od preloma su manje konzistentni. SHiper utiče na smanjenje koštane gustine $(23,37,38)$, kao i na povećanje rizika od preloma (39), što 
delom može biti povezano sa smanjenom snagom natkolenih mišića sto predstavlja i rizik od pada (40). Kod postmenopauzalnih žena sa egzogenim SHiper pokazano je sniženje koštane mase za $0,91 \%$ na godišnjem nivou (37). Takođe, sniženje koštane gustine kod osoba sa endogenim SHiper uzrokovanog nodoznom strumom je na godišnjem nivou oko $2 \%$ niže nego kod postmenopauzalnih žena lečenih tireostaticima ili radiojodom (41, 42). Aktuelni vodič za tretman SHiper savetuje tretman obolelih starijih od 65 godina života, kada je i rizik od pada i preloma daleko veći (43). Do sada nema sprovedenih studija koje su izučavale uticaj antitireoidnog tretmana i smanjenja rizika od preloma (44).

$\mathrm{U}$ dve sprovedene meta-analize $(23,42)$ pokazano je da smanjenje koštane gustine u slučajevima jatrogenog SHiper izazvanog primenom L-tiroksina u tretmanu hipotireoze kod postmenopauzalnih žena, ali ne i kod žena pre menopauze. U suprotnom, objavljeni rezultati pojedinačnih studija su kontroverzni. Tako, studije Belaya i sar. (45), Lee i sar. (46), Jamal i sar. (47), kao i Rosaria (48) pokazuju značajnu povezanost niskih vrednosti TSH kod ispitanika sa SHiper i gubitka koštane gustine, pri čemu studija Belaya i saradnika (45) tu povezanost nalazi samo kod endogenog SHiper, dok studija Rosaria (48) pokazuje sniženu koštanu gustinu vrata butne kosti kod žena pre menopauze, a kod menopauzalnih žena i na vratu butne kosti i na lumbalnoj kičmi. Studije Fabera i saradnika (42) i Greenlunda i saradnika (49) su ukazale na na pozitivan efekat u pogledu smanjenja remodelovanja kosti kod žena u menopauzi sa SHiper tretiranih radioablacijom ili tireosupresivima u odnosu na ispitanice koje nisu bile podvrgnute tretmanu. $S$ druge strane, studijama Bauera (50) i Leesea (51) nije pokazana povezanost niskog serumskog TSH i smanjenja koštane gustine i povećanog rizika od preloma. Sa kliničkog aspekta važno je istaći da kod obolelih od SHiper postoji značajnije smanjenje gustine kortikalne u odnosu na trabekularnu kost, što predstavlja objašnjenje za registrovanje nižih $\mathrm{T}$ skorova vrata butne kosti u odnosu na lumbalnu kičmu i sledstveno veći rizik od preloma kuka nego kičmenih pršljenova $(23,42,48)$. U našoj studiji, mi smo registrovali suprotno od pomenutog, kako u grupi sa SHiper, tako i u ostalim grupama koštana gustina je niža na lumbalnoj kičmi nego na LK.

Objavljeni literaturni podaci koji se odnose na uticaj SHipo na koštanu gustinu su kontroverzni $(23,44)$. Pojedine studije su ukazale da SHipo nema uticaja na koštanu gustinu, tj. da se koštana gustina obolelih od SHipo ne razlikuje od eutireoidnih (52), pa time i rizik od preloma (44).
Studija Lee i saradnika (53) ukazuje na negativan uticaj SHipo na kvalitet kosti i/ili neuromišićnu aktivnost, što zajednički doprinosi povećanom riziku od padova i sledstvenim frakturama, iako sam mehanizam i dalje ostaje nepoznat (53). Iako u dostupnoj literaturi postoji relativno mali broj studija koje su se bavile ispitivanjem povezanosti SHipo, koštane gustine i rizika od preloma, rezultati većine studija ukazuju na direktnu povezanost nivoa TSH i koštane gustine, odnosno negativnu korelaciju nivoa TSH i rizika od preloma $(24,54-56)$. Studija Lee i saradnika (46) sprovedena na 413 žena u menopauzi, ukazala je na postojanje sniženih vrednosti koštane gustine merene na vratu butne kosti u grupama ispitanica sa SHipo i SHiper $\mathrm{u}$ odnosu na eutiroidne kontrole. Slične rezultate koji pokazuju postojanje negativne korelacije između nivoa TSH i koštane gustine, objavljuju Nagata i saradnici (25). Ovi autori su na uzorku od 22 menopauzalne žene sa SHipo ukazali na značajnu negativnu korelaciju između vrednosti TSH i T skorova (25). Studijom Marawaha i saradnika (26), koja je sprovedena na 1290 premenopauzalnih ispitanica, među kojima je 175 ispitanica sa SHipo, nije pokazana povezanost nivoa TSH sa markerima koštane gustine kod obolelih od SHipo.

\section{ZAKLJUČAK}

$\mathrm{Na}$ osnovu rezultata pilot studije prikazanih u ovom radu, može se zaključiti da su supkliničke tireoidne disfunkcije povezane sa smanjenjem koštane gustine. Naši rezultati zajedno sa rezultatima iz literature (52-58) ukazuju na vezu koja postoji između SHiper i sniženih vrednosti pokazatelja koštane gustine, ali takođe, naši rezultati ukazuju da i SHipo može dovesti do gubitka koštane mase, sto sugerira da se oba poremećaja mogu uzeti u obzir kao dodatni faktori rizika za Op, posebno kod žena u menopauzi. Blagovremeno dijagnostikovanje i tretman bolesnika sa supkliničkim tireoidopatijama, posebno starijih ispitanika, bi mogli da doprinesu usporavanju gubitka koštane gustine, a time i smanjenju rizika od preloma. Međutim, odnos koristi i rizika mora biti dokazan dugoročnijim, prospektivnim, randomizovanim studijama, čime bi se anulirali ili smanjili osnovni nedostaci ove pilot-studije (veličina uzorka, pol, godine života, menopauza).

\section{ZAHVALNICA}

Ovaj rad je podržan projektom broj 173033 (E.R.I.) finansiranim od strane Ministarstva prosvete, nauke i tehnološkog razvoja.

\section{Literatura}

1. Watts NB, Bilezikian JP, Camacho PM, Greenspan SL, Harris ST, Hodgson SF et al. "American Association of Clinical Endocrinologists Medical Guidelines for Clinical Practice for the diagnosis and treatment of postmenopausal osteoporosis.“ Endocr Pract (2010) 16(suppl 3): 1-37.

2. Cooper C, Melton LJ. "The third epidemiology of osteoporosis. "Trends Endocrinol Metab (1992) 3: 224-9.
3. Bonjour JP, Theintz G, Buchs B, Sloman D, Rizzoli R. "Critical years and stages of puberty for spinal and femoral bone mass accumulation during adolescence." J Clin Endocrinol Metab (1991) 73: 555-63.

4. Surks MI, Ortiz E, Daniels GH, Sawin CT, Col NF, Cobin RH et al. "Subclinical thyroid disease: scientific review and guidelines for diagnosis and management." JAMA (2004) 291: 228-38. 
5. Biondi B, Cooper DS. "The clinical significance of subclinical thyroid dysfunction." Endocr Rev (2008) 29: 76-131.

6. Imaizumi M, Akahoshi M, Ichimaru S, Nakashima E, Hida A, Soda $\mathrm{M}$ et al. "Risk of ischaemic heart disease and all-cause mortality in subclinical hypothyroidism." JCEM (2004) 89: 3365-70.

7. Surks MI, Ocampo E. "Subclinical thyroid disease." Am J Med (1996) 100: 217-22.

8. Canaris GJ, Manowitz NR, Mayor G, Ridgway EC. “The Colorado Thyroid Disease Prevalnce Study." Arch Intern Med (2000) 160: 526-34

9. Sawin CT, Castelli WP, Hershman JM, McNamara P, Bacharach P. "The aging thyroid. Thyroid deficiency in the Framingham Study." Arch Intern Med (1985) 145: 1386-8.

10. Hollowell JG, Staehling NW, Flanders WD, Hannon WH, Gunter EW, Spencer CA et al. "Serum TSH, T4, and thyroid antibodies in the United States population (1988 to 1994): National Health and Nutrition Examination Survey (NHANES III).“ JCEM (2002) 87: 489-99.

11. Helfand M. "Screening for subclinical thyroid dysfunction in nonpregnant adults: a summary of the evidence for the U.S. Preventive Services Task Force." Ann Intern Med (2004) 140: 128-41.

12. Cooper DS, Biondi B. "Subclinical thyroid disease." Lancet (2012) 379: 1142-54.

13. Wilson GR, Curry RW Jr. "Subclinical Thyroid Disease." Am Fam Physician (2005) 72(8): 1517-24.

14. Marqusee E, Haden ST, Utiger RD. "Subclinical thyrotoxicosis." Endocrinology and Metabolism Clinics of North America (1998) 27(1): 37-49.

15. Samuels MH. "Subclinical thyroid disease in the elderly." Thyroid (1998) 8: 803-13.

16. Abe E, Marians RC, $\mathrm{Yu} \mathrm{W}, \mathrm{Wu} \mathrm{XB}, \mathrm{Ando} \mathrm{T}, \mathrm{Li} \mathrm{Y}$ et al. "TSH is a negative regulator of skeletal remodeling." Cell (2003) 115: 151-62.

17. Waung JA, Bassett JH, Williams GR. "Thyroid hormone metabolism in skeletal development and adult bone maintanance." Trends Endocrinol Metab (2012) 23: 155-62.

18. Bassett JH, Williams GR. "The molecular actions of thyroid hormone in bone." Trends Endocrinol Metab (2003) 14(8): 356-64.

19. Roberts CG, Ladenson PW. "Hypothyroidism. “Lancet (2004) 363:793803.

20. Lakatos P. "Thyroid hormones: beneficial or deleterious for bone?" Calcif Tissue Int (2003) 73(3): 205-9.

21. Vestergaard P, Mosekilde L. "Hyperthyroidism, bone mineral, and fracture risk- a meta-analysis." Thyroid (2003) 13: 585-93.

22. Faber J, Jensen IW, Petersen L, Nygaard B, Hegedüs L, Siersbaek-Nielsen K. "Normalization of serum thyrotrophin by means of radioiodine treatment in subclinical hyperthyroidism: effect on bone loss in postmenopausal women." Clin Endocrinol (Oxf) (1998) 48: 285-90.

23. Uzzan B, Campos J, Cucherat M, Nony P, Boissel JP, Perret GY et al. "Effects on bone mass of long term treatment with thyroid hormones: a meta-analysis." J Clin Endocrinol Metab (1996) 81: 4278-89.

24. Grimnes G, Emaus N, Joakimsen RM, Figenschau Y, Jorde R. „“The relationship between serum TSH and bone mineral density in men and postmenopausal women: The Tromsø study." Thyroid (2008) 18: 1147-55.

25. Nagata M, Suzuki A, Sekiguchi S, Ono Y, Nishiwaki K, Itoi T et al. "Sublcinical hypothyroidism is related to lower heel QUS in postmenopausal women." Endocr J (2007) 54(4): 625-30.

26. Marwaha KR, Garg MK, Tandon N, Kanwar R, Narang A, Sastry A et al. "Thyroid function and bone mineral density among Indian subjects." Indian J Endocrinol Metabol (2012) 16(4): 575-9.

27. Khosla S, Riggs BL. "Pathophysiology of age-related bone loss and osteoporosis." Endocrinol Metab Clin N Am (2005) 34: 1015-30.

28. Berry SD, Kiel DP, Donaldson MG, Cummings SR, Kanis JA, Johansson $\mathrm{H}$ et al. "Application of the National Osteoporosis Foundation Guidelines to postmenopausal women and men: the Framingham Osteoporosis Study." Osteoporos Int (2010) 21: 53-60.

29. Abe E, Sun L, Mechanick J, Iqbal J, Yamoah K, Baliram R et al. "Bone loss in thyroid disease: role of low TSH and high thyroid hormone." Ann N Y Acad Sci (2007) 1116:383-91.

30. Sampath TK, Simic P, Sendak R, Draca N, Bowe AE, O'Brien S et al. "Thyroid-stimulating hormone restores bone volume, microarchi- tecture, and strength in aged ovariectomized rats."J Bone Miner Res (2007) 22(6): 849-59.

31. Vestergaard P, Mosekilde L. "Fractures in patients with hyperthyroidism and hypothyroidism: a nationwide follow-up study in 16,249 patients." Thyroid (2002) 12: 411-9.

32. Solomon BL, Wartofsky L, Burman KD. "Prevalence of fractures in postmenopausal women with thyroid disease." Thyroid (1993) 317-23.

33. Morris MS. "The association between thyroid-stimulating hormone in its reference range and bone status in postmenopausal American women." Bone (2007) 40: 1128-34.

34. Baqi L, Payer J, Killinger Z, Susienkova K, Jackuliak P, Cierny D et al. "The level of TSH appeared favourable in maintaining bone mineral density in postmenopausal women." Endocr Regul (2010) 44: 9-15.

35. Taylor PN, Razvi S, Pearce SH, Dayan CM. "Clinical review: a review of the clinical consequences of variation in thyroid function within the reference range." JCEM (2013) 98: 3562-71.

36. Akalin A, Colak O, Alatas O, Efe B. "Bone remodeling markers and serum cytokines in patients with hyperthyroidism." Clin Endocrinology (Oxf) (2002) 57: 125-9.

37. Faber J, Galloe AM. "Changes in bone mass during prolonged subclinical hyperthyroidism due to L-thyroxine treatment: a meta-analysis." EJE (1994) 130: 350-6.

38. Toft AD. "Clinical practice: subclinical hyperthyroidism." NEJM (2001) 345(7): 512-6.

39. Boindi B, Palmieri EA, Klain M, Schlumberger M, Filetti S, Lombardi G. "Subclinical hyperthyroidism: clinical features and treatment options." EJE (2005); 152: 1-9.

40. Morrison A, Fan T, Sen SS, Weisenfluh L. "Epidemiology of falls and osteoporotic fractures: a systematic review." Clinicoecon Outcomes Res (2013) 5: 9-18.

41. Mudde AH, Houben AJ, Nieuwenhuijzen Kruseman AC. "Bone metabolism during anti-thyroid drug treatment of endogenous subclinical hyperthyroidism." Clin Endocrinol (Oxf) (1994) 41: 421-4.

42. Faber J, Jensen IW, Petersen L, Nygaard B, Hegedus L, Siersbaek-Nielsen K. "Normalization of serum thyrotrophin by means of radioiodine treatment in subclinical hyperthyroidism: effect on bone loss in postmenopausal women." Clin Endocrinol (Oxf) (1998) 48(3): 285-90.

43. Bahn RS, Burch HB, Cooper DS, Garber JR, Greenlee MC, Klein I et al. "American Thyroid Association. Hyperthyroidism and other causes of thyrotoxicosis: management guidelines of American Thyroid Association and American Association of Clinical Endocrinologists." Endocr Pract (2011) 17: 456-520.

44. Wirth CD, Blum MR, da Costa BR, Baumgartner C, Collet T-H, Medici $\mathrm{M}$ et al. "Subclinical thyroid dysfunction and the risk for fractures. A systematic review and meta-analysis." Ann Intern Med (2014) 161: 189-99.

45. Belaya ZE, Melnichenko GA, Buzhinskaya LY, Fadeev VV, Alekseeva TM, Dorofeeva OK et al. "Subclinical hyperthyroidism of variable etiology and its influence on bone in postmenopausal women." Hormones (2007) 6(1): 62-70

46. Lee WY, Oh KW, Rhee EJ, Jung CH, Kim SW, Yun EJ et al. "Relationship between subclinical thyroid dysfunction and femoral neck bone mineral density in women."J Arch Med Res (2006) 37: 511-6.

47. Jamal SA, Leiter RE, Bayoumi AM, Bauer DC, Cummings SR. "Clinical utility of laboratory testing in women with osteoporosis." Osteoporos Int (2005) 16(5): 534-40.

48. Rosario PW. "Bone and heart abnormalities of subclinical hyperthyroidism in women below the age of 65 years." Arq Bras Endocrinol Metabol (2008) 52(9): 1448-51.

49. Greenlund LJ, Nair KS, Brennan MD. "Changes in body composition in women following treatment of overt and subclinical hyperthyroidism." Endocr Pract (2008) 14(8): 973-8.

50. Bauer DC, Nevitt MC, Ettinger B, Stone K. "Low thyrotropin levels are not associated with bone loss in older women: a prospective study." J Clin Endocrinol Metab (1997) 82: 2931-6.

51. Leese GP, Jung RT, Guthrie C, Waugh N, Browning MC. "Morbidity in patients on L-thyroxine: a comparison of those with a normal TSH to those with a suppressed TSH." Clin Endocrinol (Oxf) (1992) 37(6): 500-3 
52. Kim K-C, Lee Y-K, Lee YJ, Ha Y-C, Koo K-H. "Bone health and Clinical Results after Hip fracture surgery in patients with subclinical hypothyroidism." J Bone Metab (2014) 21: 213-6.

53. Lee JS, BužkovaP, FinkHA, VuJ, CarboneL, ChenZetal. "Subclinical thyroid dysfunction and incident hip fracture in older adults." Ann Intern Med (2010) 170(21): 1876-83.

54. Vestergaard P, Rejnmark L, Weeke J, Mosekilde L. "Fracture risk in patients treated for hyperthyroidism." Thyroid (2000) 10: 341-8.

55. Arata N, Momotani N, Maruyama H, Saruta T, Tsukatani K, Kubo A et al. "Bone mineral density after surgical treatment for Graves' disease." Thyroid (1997) 7: 547-54.
56. Bertoli A, Fusco A, Andreoli A, Magnani A, Tulli A, Lauro D et al. "Effect of subclinical hypothyroidism and obesity on whole-body and regional bone mineral content." Horm Res (2002) 57: 79-84.

57. Dhanwal DK. "Thyroid disorders and bone mineral metabolism." Indian J Endocrinol Metab. (2011) 15(Suppl2): S107-S112.

58. Colaianni G, Cuscito C, and Colucci S. "FSH and TSH in the Regulation of Bone Mass: The Pituitary/Immune/Bone Axis. " Clin Dev Immunol (2013) Article ID 382698:1-6. 